\title{
Sorption-probiotic supplement in the diet of calves and its effect on the functional maturity of their rumen, morpho-biochemical blood status and productivity
}

\author{
Evdokia V. Alexandrova, Oleg A. Desyatov*, Vasily E. Ulitko, and Alexey V. Kornienko \\ Ulyanovsk State Agrarian University, Ulyanovsk 432017, Russia
}

\begin{abstract}
This research considers the use of the sorption-probiotic supplement Biopinnular in the amount of 0.5 and $1.0 \%$ of the dry matter in the diets of calves of the dairy period. The results allows us to correct the microbiocenosis in the in the digestive tract by suppressing the development of pathogenic microflora and increased reproduction of Lacto- and Bifido bacteria. The studied supplement also contributes to deeper fermentation of fodder mass during digestion in the rumen, which is manifested in an increase in active acidity $(\mathrm{pH})$, cellulolytic activity of bacteria, VFA content as the main product of carbohydrate fermentation, as well as enhanced ammonia-binding function of microflora, which led to better energy and protein availability of their body. This is confirmed by indicators of the morphological and biochemical status of the blood of calves, manifested in a real increase in their red blood cells, hemoglobin, protein and protein fractions. All this was confirmed by the intensity of their live weight gain, accompanied by large average daily (by 8.83 and 23.70 $\%$, respectively) and relative (by 1.63 and $3.86 \%$ ) weight gains and smaller (by 0.44 and 0.64 ) EFU costs per unit of live weight gain. A more pronounced biological effect is observed when using a feed supplement at a dose of $1.0 \%$ of the dry matter of the diet.
\end{abstract}

\section{Introduction}

The priority area in agriculture of Russia is to provide food security as one of the main factors of socio-economic stability of the state [1]. In this aspect, dairy cattle breeding is one of the leading branches of agriculture, the productivity potential of which largely depends on the breeding effectiveness of replacement heifers. Moreover, their high growth rate is accompanied primarily by the formation of a milky type of their body constitution which is often constrained not only by increased contamination of the consumed feed with inorganic (heavy metals) and organic (mycotoxins, antigenic-foreign microflora) xenobiotics, but also by the insufficient content of mineral substances in them. In this case, optimization of the mineral nutrition of animals is ensured through the use of mineral feed supplements, whereas their price segment does not always satisfy the agricultural producer. In this connection, the replenishment of minerals in animal diets is possible through the use of cheaper natural mineral resources (vermiculite, zeolite, diatomite) which have a complex of macro- and microelements in their composition (up to 40). Their unique sorption and ion exchange properties also make it possible to reduce antigenic and toxicological load on the body [2-5].

Probiotic feed supplements are also used to increase the intensity of growth and development of calves and, above all, to reduce their death due to the occurrence of diseases of the gastrointestinal tract (GIT). The effectiveness of such supplements has been proved by numerous studies [6-8].

At present, scientists are exploring the ways of creating feed supplements with a wide range of action based on a combination of natural minerals with sorption properties and probiotic microbiota. For instance, staff members of Ulyanovsk State Agrarian University and Inzamolprom created a feed supplement Biopinnular based on the local natural silicon-containing mineral diatomite and probiotic bacteria (TU 10.91.10-00384275297-2020).

The combination of these components provides its unique sorption - probiotic properties. Studies of the effect of a complex supplement in diets of calves from birth to the age of 6 months have shown that they have a positive influence on the normalization of their digestive tract microbiocenosis, improvement of the functional maturity of the rumen, morphological and biochemical status of the blood, prevention of gastrointestinal tract diseases. And the strengthening of assimilation processes, which ultimately provide an improvement in the growth and development of young animals, their resistance to diseases, an increase in safety and productivity, which undoubtedly has scientific and practical significance and is relevant.

The purpose of the work - increasing the productivity of calves of the dairy period due to the use of a new feed additive Biopinnular in the diet and clarifying its effect on the microbiological profile of the

* Corresponding author: kormlen@yandex.ru 
gastrointestinal tract, indicators of cicatricial metabolism, morpho-biochemical status of blood and the dynamics of their live weight.

\section{Material and methods}

Scientific and economic experience was carried out on the basis of the dairy complex of the SPK im. N.K. Krupskaya Ulyanovsk region on three similar groups of calves (from the moment of their birth) of the black-and-white breed according to the scheme presented in table 1 .

Table 1. Experiment design

\begin{tabular}{|c|c|c|c|}
\hline Group & $\begin{array}{l}\text { Number } \\
\text { of } \\
\text { animals }\end{array}$ & $\begin{array}{l}\text { Duration of } \\
\text { the } \\
\text { experiment, } \\
\text { days }\end{array}$ & Feeding conditions \\
\hline I-C+ & 15 & 180 & $\begin{array}{l}\text { BD*(according to the } \\
\text { feeding scheme } \\
\text { adopted on the farm in } \\
\text { compliance with the } \\
\text { feeding rates of All- } \\
\text { Russian Institute of } \\
\text { Animal Husbandry) }\end{array}$ \\
\hline $\begin{array}{c}\mathrm{II}- \\
\mathrm{E}++\end{array}$ & 15 & 180 & $\begin{array}{l}\text { BD }+0,5 \% \text { of the } \\
\text { feed supplement } \\
\text { Biopinnular of the dry } \\
\text { matter of the diet }\end{array}$ \\
\hline $\begin{array}{l}\text { III- } \\
\text { E++ }\end{array}$ & 15 & 180 & $\begin{array}{l}\text { BD }+1 \% \text { of the feed } \\
\text { supplement } \\
\text { Biopinnular of the dry } \\
\text { matter of the diet }\end{array}$ \\
\hline
\end{tabular}

Note: BD* - basic diet, +Control, ++Experimental

All animals were kept in group stalls (15 animals in each). Their diets were made taking account of the requirements of detailed norms [9]. Differences in the feeding of calves of the compared groups consisted in the level of inclusion of the feed supplement Biopinnular in the diets of animals of groups II and III, with 0.5 and 1.0 $\%$ of its dry matter. The state of metabolism in the rumen of calves was assessed by analyzing the contents of the rumen, which was taken by a gastric tube in 4 animals from each group at the age of 3 and 6 months, on two adjacent days 3-4 hours after feeding. Moreover, the concentration of hydrogen ions $(\mathrm{pH})$, the cellulolytic activity of bacteria (CLA), the amount of volatile fatty acids (VFA), and ammonia nitrogen were determined in it [10]. Morpho-biochemical analysis of blood taken from calves aged 3 and 6 months was carried out on a BIOM01 device.

The microbiological profile of the contents of the rumen and colon in calves during these age periods was studied in the microbiological laboratory of Ulyanovsk State Agrarian University according to generally accepted tests and differential research methods [11]. The absolute and relative increase in live weight of calves was calculated according to the methods generally accepted in zootechnics, and the effectiveness of feeding the calves with a new feed additive was determined by the indicators of costs and feed payment. Differences between the studied parameters in the groups of calves were considered statistically significant at a probability level of $\mathrm{P}<0.05$ [12] MS Excel Office was used for calculations.

\section{Research results}

In the compared groups, each calf for 6 months was fed $250 \mathrm{~kg}$ of whole and $600 \mathrm{~kg}$ of skim milk replacer, $177 \mathrm{~kg}$ of compound feed, $260 \mathrm{~kg}$ of rump hay, $400 \mathrm{~kg}$ of corn silage and $100 \mathrm{~kg}$ of fodder beet, which fully covered the needs of calves in accordance with the detailed norms [9].

The consumption of the sorption-probiotic feed additive Biopinnolar by calves as part of the diet significantly corrected the microbiocenosis of their digestive tract towards the growth of obligate microflora (table 2). For instance, in calves of groups II and III (at the age of 3 and 6 months), the contents of the rumen increased in bacteria of the genus Lactobacillus in 549.57 and 1166.96 times, respectively; 16.22 and 1025.33 times, and the number of Bifidobacterium increased significantly in relation to the control calves, with a sharp decrease in the number of bacteria of the genus E. coli and Staficoccocus.

By analyzing the microbiological composition of the contents of the large intestine of calves, it was found that both 3 and 6 months of age, bacteria of the genus Lactobacillus and Bifidobacterium predominated in it over bacteria of the genus E. coli.

Thus, the use of the biopinular feed additive developed by us in the diet of calves, in the studied doses, based on the natural mineral diatomite and bacteria of the genus Bacillus subtilis, inhibits the development of opportunistic and pathogenic microorganisms in their digestive tract, and stimulates the development of Lacto and Bifidobacterium. For the entire 6-month observation period, no cases of diarrhea were observed in calves that consumed Biopinnolar supplement in the composition of the diet at a dose of $1.0 \%$, while 1 case was observed in animals that consumed it at a dose of $0.5 \%$ (i.e. $6.7 \%$ ), and in the control group diarrhea was observed in 3 animals $(20.0 \%)$.

The results of the study of metabolism processes in the rumen allow us to state (Table 3 ) that in the calves of the experimental groups at the age of 3 and 6 months there is an increase in the level of fermentation of carbohydrates which are decomposed easily and with difficulty (sugars, starch and fiber) to the final products, which is manifested firstly in the $\mathrm{pH}$ rise in group II up to 6.195 and 6.083 (P $<0.05$ ) and in group III up to 6.035 and 6.051 ( $\mathrm{P}<0.01$ ), and secondly, the concentration of VFA in the rumen fluid, respectively, up to 11.044 and 12,061 ( $\mathrm{P}<0.05-$ $0.01) \quad$ and 12.374 and 12.591 $(\mathrm{P}<0.05-0.01) \mathrm{mmol} / 100 \mathrm{ml}$, versus 6.251 and 6.243 units of active acidity and VFA - 10.500 and $11.007 \mathrm{mmol} / 100 \mathrm{ml}$ in the control group. 
Table 2. Microbiocenosis of the gastrointestinal tract of calves, million colonies forming units in $1 \mathrm{~g}$

\begin{tabular}{|c|c|c|c|c|c|c|}
\hline \multirow[t]{2}{*}{ Index } & \multicolumn{6}{|c|}{ Group } \\
\hline & $\mathrm{I}-\mathrm{C}$ & $\mathrm{II}-\mathrm{E}$ & $\begin{array}{l}\text { multiplicity of } \\
\text { changes times } \\
\text { in II to I }\end{array}$ & III - E & $\begin{array}{c}\text { multiplicity } \\
\text { of changes } \\
\text { times in III } \\
\text { to I } \\
\end{array}$ & $\begin{array}{c}\text { multiplicity } \\
\text { of changes } \\
\text { times in III } \\
\text { to II }\end{array}$ \\
\hline \multicolumn{7}{|c|}{ Microbiological profile of calves ' rumen contents } \\
\hline \multicolumn{7}{|c|}{ at 3 months of age } \\
\hline KFU E.coli & $3.685 \pm 0.586$ & $0.789 \pm 0.267 * *$ & -4.67 & $0.359 \pm 0.068 * *$ & -10.28 & -2.20 \\
\hline KFU Staficoccocus & $2.973 \pm 0.939$ & $0.433 \pm 0.048^{*}$ & -6.86 & $0.226 \pm 0.056^{*}$ & -13.14 & 1.91 \\
\hline KFU Lactobacillus & $0.029 \pm 0.009$ & $15.800 \pm 6.157 *$ & +549.57 & $33.550 \pm 8.548 * *$ & +1166.96 & +21.23 \\
\hline $\begin{array}{c}\text { KFU } \\
\text { Bifidobacterium }\end{array}$ & $0.165 \pm 0.053$ & $3.150 \pm 0.568 * *$ & +19.09 & $29.625 \pm 9.898 * *$ & +179.54 & +9.40 \\
\hline \multicolumn{7}{|c|}{ at 6 months of age } \\
\hline KFU E.coli & $0.333 \pm 0.088$ & $0.030 \pm 0.011 *$ & -11.08 & $0.004 \pm 0.001 * *$ & $\begin{array}{l}-78.24 \\
\end{array}$ & -7.06 \\
\hline KFU Staficoccocus & $2.595 \pm 0.738$ & $0.024 \pm 0.006^{*}$ & -109.26 & $0.050 \pm 0.015^{*}$ & -52.16 & +2.09 \\
\hline KFU Lactobacillus & $2.073 \pm 0.306$ & $33.625 \pm 6.452 * *$ & +16.22 & $2125.000 \pm 175.0+$ & +1025.33 & +63.20 \\
\hline $\begin{array}{c}\text { KFU } \\
\text { Bifidobacterium }\end{array}$ & $0.411 \pm 0.263$ & $4.080 \pm 1.081 * *$ & +9.93 & $36.000 \pm 5.477+$ & +87.59 & +8.82 \\
\hline \multicolumn{7}{|c|}{ Microbiological profile of the contents of the large intestine of calves } \\
\hline \multicolumn{7}{|c|}{ at 3 months of age } \\
\hline KFU E.coli & $51.625 \pm 11.995$ & $3.205 \pm 0.715^{* *}$ & -16.11 & $0.176 \pm 0.017 * *$ & -292.91 & -18.18 \\
\hline KFU Lactobacillus & $0.341 \pm 0.029$ & $51.300 \pm 20.824 *$ & +15.09 & $65.000 \pm 7.638+$ & +190.80 & +1.27 \\
\hline $\begin{array}{c}\text { KFU } \\
\text { Bifidobacterium }\end{array}$ & 0.5880 .338 & $34.750 \pm 6.524 * *$ & +59.15 & $21.250 \pm 4.956 * *$ & +36.17 & +0.61 \\
\hline \multicolumn{7}{|c|}{ at 6 months of age } \\
\hline KFU E.coli & $0.327 \pm 0.072$ & $0.016 \pm 0.006 * *$ & -20.58 & $0.002 \pm 0.001 * *$ & -163.38 & -7.94 \\
\hline KFU Lactobacillus & $0.325 \pm 0.025$ & $24.240 \pm 6.140 * *$ & +74.58 & $55.800 \pm 9.646+$ & +171.70 & +2.30 \\
\hline $\begin{array}{c}\text { KFU } \\
\text { Bifidobacterium }\end{array}$ & $0.308 \pm 0.081$ & $55.180 \pm 4.62+$ & +179.16 & $50.950 \pm 4.594+$ & +165.69 & +9.23 \\
\hline
\end{tabular}

Table 3. Indicators of scar metabolism in experimental calves

\begin{tabular}{|l|c|c|c|}
\hline \multirow{2}{*}{ Index } & \multicolumn{3}{c|}{ Group } \\
\cline { 2 - 4 } & I- & II- & III- \\
\hline \multicolumn{3}{|c|}{ at 3 months of age } \\
\hline Active acidity $(\mathrm{pH})$ & $6.251 \pm 0.009$ & $6.195 \pm 0.017^{*}$ & $6.035 \pm 0.062^{* *}$ \\
\hline Cellulolytic activity of bacteria, \% & $11.060 \pm 0.217$ & $12.243 \pm 0.433^{*}$ & $12.767 \pm 0.326^{* * *}$ \\
\hline Volatile fatty acids $(\mathrm{mmol} / 100 \mathrm{ml})$ & $10.500 \pm 0.219$ & $11.044 \pm 0.133^{*}$ & $12.061 \pm 0.309^{* *}$ \\
\hline Ammonia nitrogen, $\mathrm{mg} / \%$ & $15.943 \pm 0.464$ & $14.784 \pm 0.494$ & $14.105 \pm 0.406^{* *}$ \\
\hline \multicolumn{3}{|c|}{ at 6 months of age } \\
\hline Active acidity $(\mathrm{pH})$ & $6.243 \pm 0.042$ & $6.083 \pm 0.042^{* *}$ & $6.051 \pm 0.023^{* * *}$ \\
\hline Cellulolytic activity of bacteria, \% & $13.528 \pm 0.348$ & $15.312 \pm 0.564^{*}$ & $16.782 \pm 0.794^{* *}$ \\
\hline Volatile fatty acids $(\mathrm{mmol} / 100 \mathrm{ml})$ & $11.007 \pm 0.107$ & $12.374 \pm 0.310^{* *}$ & $12.591 \pm 0.510^{* *}$ \\
\hline Ammonia nitrogen, mg/\% & $18.130 \pm 0.654$ & $16.123 \pm 0.663^{*}$ & $15.209 \pm 0.515^{* *}$ \\
\hline
\end{tabular}

More formation in the rumen of calves of experimental groups of VFA, as the main source of their energy expenditure, provided a more intensive increase in their live weight. Along with this, the consumption of a sorption-probiotic supplement by calves in the diet improved the ammonia-binding activity of bacteria in the rumen, which was reliably (Table 3) manifested in a decrease in the content of ammoniacal nitrogen in it: at the age of 3 months by 7.27 and $11.53 \%$ and in 6 months by 11.07 and $16.11 \%$.

The results of blood tests (Table 4) confirm that its morphological and biochemical status in all experimental animals was within the physiological norm. However, there is a valid increase in the concentration of almost all blood indicators in calves, the diet of which comprised the feed supplement Biopinnular. Feeding calves with it significantly increases the level of red blood cell production and hemoglobin synthesis. For example, in the blood of calves of the second and third experimental groups at the age of 3 months, there was an increase in the number of red blood cells up to 7.80 and $8.44 \cdot 10^{12} / 1$ or by 7.59 and $16.41 \%(\mathrm{P}<0.001)$, hemoglobin - up to the level of 120.58 and $123.92 \mathrm{~g} / \mathrm{l}$, which is by 4.62 and $7.52 \%$ more than in the control group.

A similar picture can be seen in animals at the age of 6 months. In the calves of the experimental groups, there is an increase in the oxygen capacity of the blood and due to a significantly greater saturation of red blood cells with hemoglobin, compared with the animals of the control group. When using $0.5 \%$ of the feed supplement in the 
diet, the MCHC indicator was $2.63 \%$, and when it was included at a dose of $1.0 \%$, it was by 4.36 more $(\mathrm{P}<0.01)$ compared with the animals of the control group. Improving the respiratory function of the blood had a direct effect on the assimilation of the main nutrients of the feed, which is confirmed by the concentration of the total protein and its main fractions in the blood serum.

Thus, the consumption of different doses of the sorption - probiotic feed supplement Biopinnular by calves in the diet resulted in the total protein rise in blood serum up to 64.99 and $66.80 \mathrm{~g} / \mathrm{l}$ (at 3 months) and up to 68.93 and $72.67 \mathrm{~g} / \mathrm{l}$ (at 6 months), which was $(\mathrm{P}<0.001)$ more than in the blood of animals of the control group61.85 and $63.73 \mathrm{~g} / 1$ (table 4$)$. The results of the analysis of the protein spectrum in blood serum indicate a significant increase in its albumin fraction as a factor of improving the albumin-synthesizing function of the liver, which ensures protein synthesis of muscle tissue and leads to an increase in live weight gain.

Table 4. Indicators of physiological and biochemical status of blood of calves

\begin{tabular}{|c|c|c|c|c|c|c|c|c|c|c|c|}
\hline \multirow{4}{*}{\begin{tabular}{|c|} 
Grou \\
$\mathrm{p}$
\end{tabular}} & \multicolumn{11}{|c|}{ Index } \\
\hline & \multirow{3}{*}{$\begin{array}{c}\text { RBC, } \\
10^{12} / 1\end{array}$} & \multirow{3}{*}{$\begin{array}{l}\text { WBC, } \\
10^{9} / 1\end{array}$} & \multirow[t]{3}{*}{ HGB, g/1 } & \multirow{3}{*}{$\begin{array}{c}\mathrm{MCH}^{+} \\
1 \cdot 10^{-} \\
{ }^{12} \mathrm{pg}\end{array}$} & \multirow{3}{*}{$\begin{array}{c}\text { Albume } \\
n, g / 1\end{array}$} & \multicolumn{5}{|c|}{ absolute amount, $\mathrm{g} / \mathrm{l}$} & \multirow{3}{*}{$\begin{array}{l}\mathrm{A} / \mathrm{G} \\
\text { ratio }\end{array}$} \\
\hline & & & & & & \multirow{2}{*}{\multicolumn{2}{|c|}{ albumen globulin }} & \multicolumn{3}{|c|}{ including } & \\
\hline & & & & & & & & \multicolumn{3}{|c|}{\begin{tabular}{|l|l|l|}
$\mathbf{0}-$ & $\mathbf{0}-$ & $\mathbf{0}-$ \\
globulin & globulin & globulin
\end{tabular}} & \\
\hline \multicolumn{12}{|c|}{ at 3 months of age } \\
\hline \multirow[t]{2}{*}{$\mathrm{I}-\mathrm{C}$} & 7.25 & 6.15 & 115.25 & 27.78 & 61.85 & 27.73 & 34.12 & 8.69 & 6.82 & 18.61 & 0.81 \\
\hline & \pm 0.04 & \pm 0.03 & \pm 2.12 & \pm 0.38 & \pm 0.30 & \pm 0.15 & \pm 0.19 & \pm 0.64 & \pm 0.24 & \pm 0.24 & \pm 0.01 \\
\hline \multirow[t]{2}{*}{ II-E } & 7.80 & 6.22 & 120.58 & 28.52 & 64.99 & 30.18 & 34.81 & 8.96 & 6.95 & 18.90 & 0.87 \\
\hline & \pm 0.07 ** & $\pm 0.02 * *$ & $\pm 1.11^{* *}$ & \pm 0.17 & $\pm 0.34^{* * *}$ & $* \pm 0.27^{* * *}$ & \pm 0.22 & $\pm 0.15^{* *}$ & \pm 0.09 & \pm 0.18 & $\pm 0.01^{* * *}$ \\
\hline \multirow[t]{2}{*}{ III-E } & 8.44 & 6.28 & 123.92 & 28.99 & 66.80 & 31.44 & 35.36 & 9.77 & 7.05 & 18.54 & 0.89 \\
\hline & $\pm 0.13^{* *}$ & $\pm 0.01^{* *}$ & $\pm 0.69^{* * *}$ & $\pm 0.01^{* *}$ & $\pm 0.34^{* * *}$ & $\pm 0.31^{\star *}$ & \pm 0.37 & $\pm 0.08^{* *}$ & \pm 0.05 & $\pm 0.31^{* *}$ & $\pm 0.06^{* *}$ \\
\hline \multicolumn{12}{|c|}{ at 6 months of age } \\
\hline \multirow[t]{2}{*}{$\mathrm{I}-\mathrm{C}$} & 6.07 & 7.34 & 107.75 & 26.43 & 63.73 & 28.43 & 35.30 & 8.50 & 7.19 & 19.61 & 0.805 \\
\hline & \pm 0.01 & \pm 0.05 & \pm 0.89 & \pm 0.13 & \pm 0.34 & \pm 0.17 & \pm 0.20 & \pm 0.08 & \pm 0.11 & \pm 0.18 & \pm 0.005 \\
\hline \multirow[t]{2}{*}{ II-E } & 6.58 & 7.78 & 112.33 & 27.15 & 68.93 & 31.42 & 37.51 & 9.21 & 7.24 & 21.06 & 0.838 \\
\hline & $\pm 0.01^{*}$ & $\pm 0.07^{* *}$ & $\pm 1.32^{* *}$ & $\pm 0.22^{* *}$ & $\pm 0.43^{* * *}$ & $\pm 0.20^{* * *}$ & $\pm 0.23^{* *}$ & $\pm 0.21^{* *}$ & \pm 0.04 & $\pm 0.12^{*}$ & $\mid \begin{array}{c} \pm 0.006^{* *} \\
*\end{array}$ \\
\hline \multirow[t]{2}{*}{ III-E } & 7.03 & 8.25 & 115.09 & 28.30 & 72.67 & 34.38 & 38.29 & 9.69 & 7.50 & 21.10 & 0.898 \\
\hline & $\pm 0.03^{\star *}$ & $\pm 0.09 * *$ & $\pm 1.03^{* * *}$ & $\pm 0.30^{* * *}$ & $\pm 0.45^{* * *}$ & $\star \pm 0.22^{* * *}$ & $\pm 0.26^{* *}$ & $\pm 0.20^{* *}$ & $\pm 0.04^{* *}$ & $\pm 0.14^{*>}$ & $\pm 0.004^{* *}$ \\
\hline
\end{tabular}

$+\mathrm{MCH}-$ erythrocyte mean hemoglobin content, pg picogram;

$* \mathrm{P}<0.05 ; * * \mathrm{P}<0.01 ; * * * \mathrm{P}<0.001$

The globulin fraction of whey proteins is mainly responsible for the formation of the immune status and the body's resistance to diseases. The absolute amount of globulins in calves of the experimental groups at 3 months of age, and at 6 months $(\mathrm{P}<0.001)$ than in calves of the control group (table 4).

The fractional composition of globulins is of particular interest because they characterize the resistance of the organism. The absolute content of $\alpha, \beta$, and $\gamma-$ globulins in the blood serum of calves of the experimental groups was greater than that of the control peers, which indicates an increase in the functioning of liver hepatocytes and a better formation of nonspecific immunity, and an increase in the concentration of albumin confirms the intensification of assimilation processes, which ultimately determined a more intensive growth rate in the calves of the experimental groups. This is also confirmed by the protein index of the blood, that is, the ratio of albumin and globulin, which reliably reflects the degree of retention and assimilation of nitrogen in the body. The greater its absolute indicator, the more efficient is protein metabolism, which has a positive effect on the metabolism as a whole. In our studies in calves at the age of 3 months, the protein index of group III was 0.89 ; in group II -0.87 , which is by 9.87 and $7.41 \%$ more $(\mathrm{P}<0.01-0.001)$ than in the control group. A similar reliable pattern was found in calves at the age of 6 months.

Thus, feeding calves of groups II and III with the sorption-probiotic feed supplement Biopinnular in the amount of 0.5 and $1.0 \%$ of the dry matter of the diet causes not only an increase in the content of total protein in their blood serum, but also a change in the spectrum of protein fractions towards a higher content of albumin and, as a result, an increase in the protein index, which is reflected in the more intensive growth of calves of these groups. An analysis of the morphological and biochemical composition of the blood of calves indicates an increase in the experimental groups in animals, as a result of a decrease in the toxic load on their body, its respiratory function, due to a higher content of red blood cells and their saturation with hemoglobin, which contributes to a more intensive course of redox processes, and, therefore, they make better use of the energy and nutrients of the feed. These changes are most pronounced in calves when 
$1.0 \%$ of the feed supplement Biopinnular of the dry matter was included in their diet.

With almost the same live weight of calves of the compared groups kept in stalls $\left(\begin{array}{llll}34.30 & .36 .03 & \mathrm{~kg}\end{array}\right)$ (Table 5), animals that received $0.5 \%$ (group II) and $1.0 \%$ (group III) of its dry matter in the diet supplementation at the end of 6 months of age reached a live weight of 165.07 and $168.67 \mathrm{~kg}$, respectively, which is by 12.2 and $15.8 \mathrm{~kg}$ or 7.98 and $10.34 \%$ more. Moreover, the calves of these groups also had a higher growth rate. If the relative weight gain in animals of the control group was $126.69 \%$, then in calves that received the feed supplement it was by 1.63 and 3.86 absolute percent more. During the study period, the average daily weight gain in calves of group II that consumed
Biopinnular in the amount of $0.5 \%$ was $741.54 \mathrm{~g}$, which is by $8.83 \%$ more $(\mathrm{P}<0.001)$ than in animals of the control group.

A further increase in the dose of dietary supplements in the diet of calves to $1.0 \%$ of its dry matter resulted in a more significant daily increase in live weight (up to $765.68 \mathrm{~g}$, which is $12.37 \%$; $\mathrm{P}<0.001$ ) more than that of analogues from the control group. A more intense increase in live weight in the calves of the experimental groups is obviously due to the colonization of their rumen with the beneficial microflora contained in the used supplement, which accelerated its functional maturity, which was reflected in more intense processes of metabolism in the rumen.

Table 5. Dynamics of live weight of calves over the period of the experiment

\begin{tabular}{|c|c|c|c|}
\hline \multirow[t]{2}{*}{ Index } & \multicolumn{3}{|c|}{ Group } \\
\hline & $\mathrm{I}-\mathrm{C}$ & II-E & III-E \\
\hline Live weight, kg: when tested & $34.30 \pm 1.48$ & $36.03 \pm 1.55$ & $35.44 \pm 1.76$ \\
\hline at the end of the experiment & $152.87 \pm 2.09$ & $165.07 \pm 2.05 * * *$ & $168.67 \pm 2.04 * * *$ \\
\hline The gain for the experience: absolute, $\mathrm{kg}$ & $118.56 \pm 1.78$ & $129.03 \pm 1.68 * * *$ & $133.23 \pm 1.99 * * *$ \\
\hline daily average, $g$ & $681.39 \pm 10.23$ & $741.54 \pm 9.66 * *$ & $765.68 \pm 11.45 * * *$ \\
\hline in $\%$ to control & - & 108.83 & 123.70 \\
\hline relative, $\%$ & 126.69 & 128.32 & 130.55 \\
\hline Cost per $1 \mathrm{~kg}$ of growth: EKU & 5.81 & 5.37 & 5.17 \\
\hline in $\%$ to control & - & 92.43 & 88.98 \\
\hline digestible protein, $g$ & 579.72 & 532.68 & 515.88 \\
\hline Feed payment, kg & 17,21 & 18,62 & 19,34 \\
\hline in $\%$ to control & - & 108,19 & 112,38 \\
\hline
\end{tabular}

$* \mathrm{P}<0.05 ; * * \mathrm{P}<0.01 ; * * * \mathrm{P}<0.001$

Optimization of calf nutrition by including the sorption - probiotic feed additive Biopinnular in the amount of 0.5 and $1.0 \%$ of the diet dry matter in the diet provided them with respect to control calves, along with an increase in live weight gain and a decrease in the cost of EFU and digestible protein for $1 \mathrm{~kg}$ of growth, respectively, by 0.44 and $47.04 \mathrm{~g}$ in calves of the second group and by 0.64 and $63.84 \mathrm{~g}$ in the third, and the rate of payment for feed in group II was higher by $8.19 \%$, and in group III - by $12.38 \%$ in relation to the control group.

\section{Conclusion}

Thus, the use of the sorption-probiotic supplement Biopinnular in the amount of 0.5 and $1.0 \%$ of the dry matter of the diet during the milk period of growing calves allows us optimize the microbiological profile in the rumen and large intestine), towards increased development of Lacto- and Bifido bacteria in them and suppression of the reproduction of pathogenic microflora. The additive under study also promotes deeper fermentation of the fodder mass during cicatricial digestion, which is manifested in an increase in active acidity $(\mathrm{pH})$, the activity of bacteria destroying fiber, the concentration of VFA as the end product of carbohydrate fermentation, as well as an increase in the ammoniabinding activity of bacteria, which caused better energy and protein supply of their body. This is confirmed by indicators of the morphological and biochemical status of the blood of calves, manifested in a real increase in their red blood cells, hemoglobin, protein and protein fractions. All this was confirmed by the intensity of their live weight gain, accompanied by large average daily (by 8.83 and $23.70 \%$, respectively) and relative (by 1.63 and $3.86 \%$ ) weight gains and smaller (by 0.44 and 0.64) EFU costs per unit of live weight gain. A more pronounced biological effect is observed when using a feed supplement at a dose of $1.0 \%$ of the dry matter of the diet.

\section{References}

1. E.N. Krylatykh, E.Yu. Frolova, International agribusiness and food security (expert discussion of the Gaidar forum-2016), Econ. of agricult. and proc. enterpr., 3, 28-31 (2016)

2. M.A. Verotchenko, Morphological composition of calves' blood when using the mineral Supplement vermiculite in feeding, in: Mater. of the int. sci. and pract. Conf. dedicated to the 90th annivers. of the viz. Ernst (2019) pp. 106-110

3. E.M. Tikhonova, A.Yu. Nechaev, I.V. Lunegova et al., Influence of innovative feed mixture "Vetohit" on the growth and development of calves in the dairy growing period, Quest. of normat. legal regulat. in veter. Med., 1, 100-102 (2017)

4. V.E. Ulitko, Res. J. of pharmac. Boil. and chem. Sci., 9, 4 (2018) 
5. Yu.V. Semenova, L.A. Pykhtina, A.V. Shchuklina, Vest. of Ulyanovsk state agricult. Acad., 4(40) (2017)

6. I.A. Alekseev, R.A. Egorov, Non-Specific immunity in calves in the conditions of a dairy complex against the background of the use of "Basulforoa", Sci. notes of the Kazan state Acad. of veter. Med. named after N.E. Bauman, 239, 4-8 (2019)

7. O.I. Bobrovskaya, R.V. Nekrasov, A.T. Mysik et al., Enzyme-probiotic and synbiotic preparations in the diet of piglets, Husbandry, 12, 13-16 (2011)

8. R.V. Nekrasov, M.G. Chabaev, A.A. Zelenchenkova et al., Efficiency of feeding a new probiotic based on spore-forming bacteria to calves of the dairy growing period, Agrar. Sci., 2, 24-27 (2016)
9. A.P. Kalashnikov, Norms and rations for feeding farm animals (reference guide) (Moscow, 2003) 456 p.

10. Study of digestion in ruminants, Methodical instructions (All-Russ. Res. Instit. of physiol., biochem. and nutrit. of agricult. animals RASKHN, 1979) $140 \mathrm{p}$.

11. B.V. Tarakanov, Methods of research of microflora of the digestive tract of agricultural animals and birds (Nauchny Mir, Moscow, 2006) 188 p.

12. N.A. Plochinsky, Biometriya (Moscow State University, Moscow, 1970) 336 p. 